\title{
Indigenous Occupational Practices and Apprenticeship: Implications for Personal Development of Youths in South-West Nigeria

\author{
Obadara, Olabanji E. (Ph.D.)
}

\author{
Department of Educational Management, \\ Tai Solarin University of Education, Ogun State, Nigeria. \\ doctorobadara@yahoo.co.uk
}

\author{
Abatan 0. Luke \\ Department of Languages \\ Tai Solarin University of Education, Ogun State, Nigeria. \\ lukeabatan@yahoo.com
}

Doi:10.5901/ajis.2014.v3n1p393

\begin{abstract}
The study examined the relationship between indigenous occupational practices and apprenticeship, and personal development of youth in the south-west Nigeria. Descriptive survey research design was used for the study. The sample of 200 apprentices was drawn from 5 indigenous occupations selected in the south west Nigeria. A total number of 40 apprentices were drawn from each indigenous occupation using purposive non-probability sampling for the study. The study developed and used a questionnaire tagged: "Indigenous Occupational Practice and Apprenticeship, and Personal Development Questionnaire (IOPAPDQ)" with a reliability coefficient $(r=0.81)$ and complimented with interview for data gathering. Out of the 200 respondents were 119 males and 81 females youths with ages range between 15 and 25 years. Descriptive statistic of percentage as well as inferential statistic of Pearson Product Moment Correlation Coefficient ( $r$ ) was used for the data analysis. While the null hypotheses developed for the study were tested at 05 level of significance. The findings revealed that 64 percent of the apprentices observed are youths that have at least secondary school education while 36 percent do not, and there is significant relationship between pot making, blacksmithing, farming, adire textile, carving and personal development of youth in the south-west Nigeria. It is therefore recommended among others that the trainers and other leaders in the workplace should make regular visits and contact with apprentices in the workplace; the apprentices should always be exposed to more site or trial periods on the job so as to develop their skills in the occupations. Finally, apprenticeship in indigenous occupations should be designed in a way to provide adequate technological orientation and preparation for career development.
\end{abstract}

Keywords: Traditional occupations, Human capital, Technical and vocational training, Skills acquisition, Self-reliance, Development.

\section{Introduction}

The increasing rate of population explosion and consequently unemployment and unemployability, which have continually been posing social and economic problems to both government and individuals call for serious attention on the part of the government and the entire country. Parents and guardians are desirous of the ability of their children and wards to find or create jobs after course training. This training involves the acquisition and development of marketable skills that are related to the ever-changing business oriented society. The problem with Nigeria today is basically the underproduction of graduates that will meet the demands of the rapidly changing employment community. Technical and vocational training should help the trainees acquire and develop these needed skills and attitudes for employment. It is equally observed that the traditional informal apprenticeship is recognised everywhere as a powerful process of training for young persons in different skills and vocations.

Personal development is the process of improving oneself through such activities as enhancing employment skills, increasing consciousness and building wealth. The growing success of the self-help and personal development movement has assisted many business managers in obtaining more qualified and motivated personnel for their companies and it has also encouraged more people to go into business for themselves. It includes activities that improve awareness and identity, develop talents and potential, build human capital and facilitate employability, enhance quality of life and contribute to the realization of dreams and aspirations. The concept is not limited to self-help but includes formal 
and informal activities for developing others in roles such as teacher, guide, counselor, manager, life coach or mentor. When personal development takes place in the context of institutions, it refers to the methods, programmes, tools, techniques, and assessment systems that support human development at the individual level in organizations (Aubrey, 2010).

At the level of the individual, personal development includes the following activities:

- improving self-awareness

- improving self-knowledge

- building or renewing identity/self-esteem

- developing strengths or talents

- improving wealth

- spiritual development

- identifying or improving potential

- building employability or human capital

- enhancing lifestyle or the quality of life

- improving health

- fulfilling aspirations

- initiating a life enterprise or personal autonomy

- defining and executing personal development plans

- improving social abilities

The concept according to Boreham, Fischer, \& Samurcay (2002) covers a wider field than self-development or selfhelp: personal development also includes developing other people. This may take place through roles such as those of a teacher or mentor, either through a personal competency (such as the skill of certain managers in developing the potential of employees) or a professional service (such as providing training, assessment or coaching).

Any sort of development - whether economic, political, biological, organizational or personal - requires a framework if one wishes to know whether change has actually occurred. In the case of personal development, an individual often functions as the primary judge of improvement, but validation of objective improvement requires assessment using standard criteria. Personal development frameworks may include goals or benchmarks that define the end-points, strategies or plans for reaching goals, measurement and assessment of progress, levels or stages that define milestones along a development path, and a feedback system to provide information on changes.

Apprenticeships combine the development of theoretical knowledge about a particular occupation or range of occupations with practical experience gained from doing the job. Apprenticeship training should lay the foundation for occupational competence and the capacity to add to this as required throughout working life (Macleod and Hughes, 2006). It should be noted that there is no commonly agreed definition of what constitutes an apprenticeship. The Modern Apprenticeship Advisory Committee (2001) proposed a number of defining elements of an apprenticeship as a form of personal development which should:

- include an agreement by an employer to train a person, using the practices, equipment and personnel of his or her enterprise in doing so

- use a mixture of on-the-job and off-the-job learning

- lead to public recognition on completion that the apprentice has achieved proficiency in a trade, profession or occupation.

Ryan and Unwin (2001) describe apprenticeship as a structured programme of vocational preparation, sponsored by an employer, juxtaposing part-time education with on-the-job training and work experience, leading to a recognized vocational qualification at craft or higher level, and taking at least two years to complete, after requisite general education.

Fuller and Unwin (2003) add another element; they argue that a crucial element is the sharing of costs between the employer (paying the apprentice's wages) and the state (funding the qualification components). The website of the former Sector Skills Development Agency on other hand defines apprenticeships thus:

An apprenticeship is a nationally recognised training programme combining real work with learning and training, both on and off the job. An apprentice may receive a wage, whilst training and working towards the full apprenticeship. If an apprentice does not receive a wage they will receive an allowance from the government. All apprentices on a level three will be paid by their employer (SSDA, 2003).

The apprenticeship programme consists of a number of component parts. Through the programme an apprentice 
will develop and demonstrate their knowledge and skills and prove their occupational competence whilst also demonstrating that they have met the standards in key skill areas such as numeracy, literacy and communication. The remaining part of the apprenticeship is being aware of, and having an understanding of employment rights and responsibilities. Whilst these individual parts may be assessed separately, only when all parts are successfully achieved will an apprentice receive an apprenticeship certificate.

Apprenticeship provides experiences that actualize the new capacities that arrive with adolescence, whether for planning, managing and sustaining effort, regulating emotional states, developing the skills of judgment, reflecting and self-correcting, or other (Larson, Hansen, \& Walker, 2005). Apprenticeship is characterized by a distinct adult-youth relationship (Halpern, 2005). The relationship is task focused, not youth focused. The apprentice has some volition, a fact important to youth, but the adult structures tasks to create a sequence tied to the apprentice's growing experience. The adult does some teaching and is authoritative, but he or she is also an "exemplar," modeling skilled practice and the general behaviour of one with that particular identity. The adult's discourse is typically task oriented, concrete, and specific. Identification with the adult as a skilled professional in a particular discipline becomes, over time, one motive for learning and part of the learning process. In Nigeria, apprenticeship system arose as a family institution, as a means of supplying artisans for the various crafts then in existence and as a means of propagating the heritage of the family (Agboola \& Olaoye, 2008).

\section{Purpose of the Study}

The purpose of this study was to establish empirically the relationship between indigenous occupational practice and apprenticeship, and personal development of youth in the South-West Nigeria. Specifically, it explores the contribution of indigenous occupational practices and apprenticeship to the personal development of youth with the view to make useful recommendations on the improvement of skills, competence and personal development of youth in the South-West Nigeria.

\section{Research Questions}

The following research questions were raised to guide the study.

- What are indigenous occupational practices in the South-West Nigeria?

- Is there any relationship between indigenous occupational practices and apprenticeship, and personal development of youth in the South-West Nigeria?

\section{Research Hypotheses}

The following null hypotheses were developed and tested in the study.

- Ho1: There is no significant relationship between pot making and personal development of youth in the SouthWest Nigeria.

- Ho2: There is no significant relationship between blacksmithing and personal development of youth in the South-West Nigeria.

- $\mathrm{H}_{3}$ : There is no significant relationship between farming and personal development of youth in the SouthWest Nigeria.

- H04: There is no significant relationship between Adire textile and personal development of youth in the SouthWest Nigeria.

- H05: There is no significant relationship between carving and personal development of youth in the SouthWest Nigeria.

\section{Research Procedure}

Descriptive survey research design was used for the study. The sample of 200 apprentices was drawn from 5 indigenous occupations selected in the South West Nigeria. A total number of 40 apprentices were drawn from each indigenous occupation using purposive non-probability sampling for the study. The study developed and used a questionnaire tagged: "Indigenous Occupational Practice and Apprenticeship, and Personal Development Questionnaire (IOPAPDQ)" with a reliability coefficient $(r=0.81)$ and complimented with interview for data gathering. Out of the 200 respondents 
were 119 males and 81 females youths with ages range between 15 and 25 years. The data collected were analysed using descriptive statistic of simple percentage and inferential statistic of Pearson Product Moment Correlation Coefficient (r). While the null hypotheses developed for the study were tested at the .05 level of significance.

\section{Results and Discussion}

The results of the study are presented according to the developed research question and hypotheses. What are indigenous occupational practices in the South-West Nigeria?

Table 1: Indigenous Occupation Practice \& Total Number of Apprentices

\begin{tabular}{|c|l|c|c|c|}
\hline S/N & $\begin{array}{c}\text { Indigenous } \\
\text { Occupational Practice }\end{array}$ & $\begin{array}{c}\text { Total No. of } \\
\text { Apprentices }\end{array}$ & $\begin{array}{c}\text { Total No. of Secondary Sch. } \\
\text { Graduate \& Above }\end{array}$ & $\begin{array}{c}\text { \% of Secondary Sch. } \\
\text { Graduate \& Above }\end{array}$ \\
\hline 1 & Pot Making & 40 & 08 & 20 \\
\hline 2 & Blacksmithing & 40 & 20 & 50 \\
\hline 3 & Farming & 40 & 35 & 87.5 \\
\hline 4 & Adire Textile & 40 & 36 & 90 \\
\hline 5 & Carving & 40 & 29 & 64 \\
& TOTAL & 200 & 128 & 62.5 \\
\hline
\end{tabular}

The Table 1 above shows the indigenous occupational practices and the total number of apprentices, the total number of secondary school graduates and above among apprentices, and their percentages in each of the 5 indigenous occupations used for the study. The analysis shows that the highest number of secondary school graduates and above among apprentices is 36 recorded in Adire textile representing $90 \%$ of the sample. It is followed by 35 apprentices in farming which is 87.5\%, 25 apprentices in carving amounted to 72.5\%, 20 apprentices in blacksmithing which is 50\%, and 8 apprentices in pot making representing $20 \%$ of the sample in that order. This indicates that the remaining 72 apprentices representing $36 \%$ of the total apprentices are other youths that do not have secondary school education; they are either dropouts or primary school leavers.

Table 2: Relationship between Indigenous Occupational Practices and Apprenticeship and Personal Development in South-West Nigeria

\begin{tabular}{|l|c|c|c|c|c|}
\hline \multicolumn{1}{|c|}{ Variable } & N & df & Observed(r) & Tabulated(r) & Remark \\
\hline Pot Making & 40 & 198 & 0.84 & .159 & Sig. \\
\hline Blacksmithing & 40 & 198 & 0.89 & .159 & Sig. \\
\hline Farming & 40 & 198 & 0.66 & .159 & Sig. \\
\hline Adire Textile & 40 & 198 & 0.76 & .159 & Sig. \\
\hline Carving & 40 & 198 & 0.92 & .159 & Sig. \\
\hline Personal Development (Constant) & 200 & - & - & - & - \\
\hline
\end{tabular}$<0.05$

The Table 2 above shows the relationship between indigenous occupational practices and apprenticeship and personal development of youth. It reveals significant relationship between pot making and personal development. $(r=0.84, p<$ $0.05)$, blacksmithing $(r=0.89, p<0.05)$, farming $(r=0.66, p<0.05)$, adire textile $(r=0.76, p<0.05)$, carving $(r=0.92, p$ $<0.05$ ) and personal development. Since the observed $r$ - values of each of all the indigenous occupational practices and apprenticeship is greater than the tabulated $r$ - values, all the null hypotheses developed for the study are rejected. So there is significant relationship between pot making, blacksmithing, farming, adire textile, carving and personal development of youth in the south-west Nigeria.

The above stated results have shown that the indigenous occupational practices and apprenticeship is significantly related to personal development of youth in the south-west Nigeria. These present findings are in agreement with the findings of Larson, Hansen, \& Walker (2005) and Halpern (2005), who observed that apprenticeship as usual is a practice in indigenous occupations that develops cordial relationship between the supervisor/ mentors and the trainees immensely contributed to the personal development of young ones. It is widely accepted that organizational and occupational changes have resulted in an increased demand from employers for broader-based forms of skill. The relationship 
between types of work and types of broad skill(s) needed for each occupation call the young people for regular development in skills acquisition in following types of generic skill: (a) resituating existing knowledge or skill in a new context to help solve a routine problem or unforeseen event or problematic situation (Boreham and Fischer, 2002); (b) participating in a workplace community of practice to gain access to human and technological resources residing in such communities and needed to solve routine or unforeseen problems (Tuomi-Gröhn and Engeström, 2003); (c) working collaboratively with others to address novel problems (Eraut, 1999).

There is no doubt that indigenous occupations are important sources of maintenance of indigenous cultures and means of their economic self-reliance and development. Most indigenous peoples have developed highly specialized livelihood strategies and occupations, which are adapted to the conditions of their traditional territories and are thus highly dependent on access to lands, territories and resources (Eraut, 2004). Such traditional occupations include handicrafts, rural and community-based industries and activities such as hunting, fishing, trapping, shifting cultivation or gathering. In some cases, indigenous peoples are simply identified by their traditional occupations, as, for example, pastoralists, shifting cultivators and hunter-gatherers, pot-making, adire textile, etc.

The nature of the iindigenous occupational practices and apprenticeship varies from one occupation and tribe to the other. There are no laws guiding the number of apprentices to be recruited, the system allows for free entry and exit of apprentice at will. Evidence has shown that the more difficult it is for a person to qualify for an occupation, the fewer the people that are engaged in it and invariably the higher the remuneration and prestige attached to such an occupation. But the case is different in indigenous occupational practices and apprenticeship. The tenure of apprenticeship in indigenous occupations is usually fixed by the trainer and based on agreement of the trainer and the trainee or/and trainee's guardian(s). The youth that graduate must have been introduced to the fundamental of the vocation or skill such as the techniques or methods, materials, particular tools or technology, language, components or dimensions of skills or vocations needed. This is done by allowing the apprentices to begin to develop the approach of an expert in the discipline. This means looking at one's own or others' work with a "knowledgeable eye" or developing an educated aesthetic sense. It means being able to visualize what the craft or vocation is all about. A higher level of expertise means being able to describe what one is doing or aiming for in a creative piece of work. However, there is a number of challenges for the design and delivery of apprenticeships such as:

- A lack of employer demand and commitment to the idea of ownership, including limited take-up by small and medium enterprises.

- Problems relating to the participation and successful achievement of apprenticeships by young people, resulting from candidates being poorly equipped educationally and attitudinally to complete programmes, as well as gender and racial barriers to participation.

- Issues relating to the appropriate content of apprenticeships, including concerns about a lack of underpinning technical knowledge.

\section{Conclusion}

Apprenticeships are one of the oldest established institutions in education and training. They often involve some forms of blended on-and off-the-job training. An ideal apprenticeship system will involve high quality training providing transferable as well as occupation-specific skills. Apprenticeship is an informal education with a difference. It is a concept best practised in indigenous occupations that begins with finding an employer. Employers hire apprentices, pay their wages and provide on-the-job training and work experience. Approximately 80 percent of an apprentice's time is spent on the job under the supervision of a certified journeyperson or qualified tradesperson. The other 20 percent involves technical training provided at, or through the informal institution.

The model of work experience here is concerned with 'launching' trainees into the world of work. This model reflects the traditional aim of apprenticeship based work experience programmes of moulding and adapting trainees' skills in the workplace. These skills indeed contribute greatly to youth personal development. It should also be noted that some of the cultural heritage of the indigenes that are known with various occupations will be imparted into the trainees. This is because of the cultural issues within business sectors relating to established working practices and recruitment preferences within particular sectors.

\section{Recommendations}

In light of the above findings, the following recommendations are proffered. It is important that the attitude of people 
should be changed so that apprentices are no longer used as cheap labour, they should be adequately paid. Workplaces need more training and guidance when appointing apprentices therefore, supervisors need to know what to expect from an apprentice and how to supervise, train and coach them. The trainers and other leaders in the workplace should make regular visits and contact with apprentices in the workplace; the apprentices should always be exposed to more site or trial periods on the job so as to develop their skills in the occupations.

Clear expectations of trainers in indigenous occupations should be set since we need guidance on what we should be doing with apprentices for their development. The apprentices should be employed for the right reasons, not just because the workplace is busy. Finally, apprenticeship in indigenous occupations should be designed in a way to provide adequate technological orientation and preparation for career development.

\section{References}

Agbola, T. and Oloaoye, O.O. (2008). Labour supply and manpower development strategies in the Nigerian building industry. A paper presented at the first departmental staff/students seminar, Department of Urban and Regional Planning, University of Ibadan, 15th January.

Aubrey, B. (2010). Managing your aspirations: Developing personal enterprise in the global workplace. New York: McGraw-Hill. pp. 9.

Boreham, N., \& Fischer, M. (2002). Work process knowledge. London: New York: Routledge.

Eraut, M. (2004). Deconstructing apprenticeship learning: What factors affect its quality? In R. Mulder \& P. F. E. Sloane (Eds.), New approaches to vocational education in Europe: The construction of complex learning-teaching arrangements. Oxford: Symposium pp. 45 - 57.

Eraut, M. (1999). Learning in the workplace - a framework for analysis. Paper presented at the EARLI Conference on Working and Learning, July.

Fuller, A. \& Unwin, L. (2001). Context and meaning in apprenticeship: Illuminating workplace learning. Paper presented at TLRP International Workshop, University College Northampton.

Halpern, R. (2005). Instrumental relationships: A potential relational model for inner-city youth programmes. Journal of Community Psychology, 33(1), 11 - 20.

Larson, R., Hansen, D., \& Walker, C. (2005). Everybody's gotta give: Development of initiative and teamwork within a youth programme. In J. Mahoney, R. Larson, \& J. Eccles (Eds.), Organized activities as contexts of development: extracurricular activities, afterschool and community programmes. Mahwah, NJ: Lawrence Erlbaum. pp. 159 - 184.

Macleod, D. and Hughes, M. (2006). Apprenticeships: A review of recent policy and practice. LSC.

Modern Apprenticeship Advisory Committee (2001). Modern apprenticeships: The way to work, The Report of the Modern Apprenticeship Advisory Committee London: DFES.

Ryan, P. \& Unwin, L. (2001). Apprenticeship in the British Training Market, National Institute Economic Review, 178,99 - 114.

Sector Skills Development Agency (2003). SSDA news bulletin, Involve, 43, November, 59.

Tuomi-Gröhn, T. \& Engeström, Y. (Eds.). (2003). New perspectives on transfer and boundary crossing. Amsterdam: Elsevier. 